\title{
VERS DE JEUNESSE JUVENILIA
}




\section{Ode au chapeau...}

Ode au chapeau (système gibus) de M. Lamare, professeur d'histoire

au lycée impérial de Saint-Brieuc (Musée et Bibliothèque), archiviste

et antiquaire de la ville, agrégé de la faculté des..., officier d'académie

inventeur de la chaîne de montre en or des gens qui nont pas les moyens

de se procurer des chaînes en cuivre.

\section{INVOCATION}

Venez, Muses, venez neuf sœurs

accorder ma cythare

Je chante le taf à Lamare

le plus cruel de tous mes professeurs

Et puissent mes vers si faibles par eux-mêmes

être grandis par le noble sujet

Que jembrasse en chantant ce couvre-chef suprême ce respectable objet

\section{AU CHAPEAU}

Noble débris (jallais dire sans tache)

De la gloire de nos ayeux

Toi qui jadis bravas la francisque et la hache

Du sarrazin audacieux

Qui suivant de Clovis la vagabonde course vis le Rhône effrayé remonter vers sa source

Du bruit de ses exploits

Viens et que ma lyre

Oubliant la satyre

Chante la splendeur d'autrefois

Oui ton nom est inscrit au temple de mémoire ô féodal gibus

Oui ton nom est inscrit à l'autel de la gloire parmi ceux des Romains en US. 


\section{Ode to the hat}

Ode to the hat (opera-hat collapsible) of M. Lamare, history teacher at the Imperial

Grammar School of Saint Brieuc (Museum and Library), archivist and antiquary of

the town, with a master's degree from the Faculty of ....., academician, inventor of

the gold watch-chain for those who cannot afford brass ones.

\section{Invocation}

Come, Muses nine, sisters in cahoots,

And tune my cithara (they're like lutes),

I sing the topknot,

Or rather the topper, of a certain Monsieur Lamare

By far

The cruellest teacher I have got.

May my verses, so feeble in themselves, become more delectable

Enhanced by their noble subject matter.

And as I sing this distinguished headgear let me kiss the respectable

Object, showpiece of any hatter.

\section{To the hat}

Noble remnant (I nearly said none could match it)

Of our ancestors' capacity

For renown, you who, braving battleaxe and hatchet

Of Saracen audacity

In the wake of Clovis winding his way ahorse

Saw the Rhône startled back up to its source,

Of such exploits should you hear

Come and may my lyre

Dispensing with barbs of satire

Sing the splendour of yesteryear.

Yes your name's engraved in the temple of memory

O opera hat of feudal fame

Yes your name's engraved on the altar of glory

Along with every -us Roman name. 
92 Oysters, nightingales and cooking pots

\section{Trois quatrains}

\section{I}

sous les griffes d'un professeur ma muse reste emprisonnée mais elle paraîtra dans toute sa splendeur une fois sorti (sic) du Lycée.

II

Bonsoir ô purs plaisirs où mon âme ravie Aimait à sélever vers Dieu

Et vous ô bons dîners le soutien de ma vie Un dernier et suprême adieu.

III

À eux le latin de cuisine

Qu'ils courent après pauvres fous

À eux la version latine

Mais la narration est à nous. 


\section{Three quatrains}

I

in a certain teacher's claws my tender

muse remains imprisoned, a tool,

but she will appear in all her splendour

once I'm clear of this Grammar school.

II

O purest pleasures, my soul's delight, My way up to God, I wish you goodnight;

And you life-sustainers, scrumptious dinners, to you

A last supreme adieu.

\section{III}

Let them, poor fools, keep the dog Latin prizes

They're chasing after, barking in chorus...

Let them keep translation exercises,

Narrative's the thing for us.

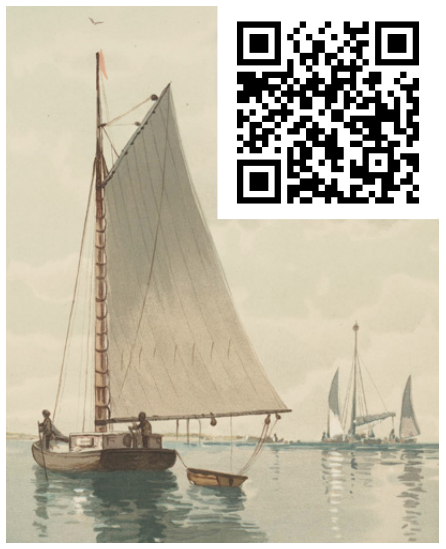

Video 7: Trois quatrains / Three quatrains Watch a reading of this poem at https:// doi.org/10.22599/Corbiere.7 or scan the QR code. 
Véritable complainte d'Auguste Berthelon

MORT À L'ART FIN COURANT SUR L'AIR DE...

DANS SA VILLA SAN CREPINA (ROUTE DE PARIS)

Ah! Chantons à perdre haleine,

Chantons à cris et à cors

Le dernier hymne du cor-

Donnier brisant son alène!

Pleurons avec des oignons

Le néant de Berthelon.

Il marche dans la carrière,

D’un glorieux vernis couvert,

Dans le soulier découvert

Et la botte à l'écuyère;

Ayant tant fait dans les peaux,

Il va perdre du repos!

Ah! voyez suinter les larmes

Dans tous les œils-de-perdrix:

On en sent bien tout le prix

Car la botte d'un gendarme

Reçoit comme un bénitier

Le pleur coulant de nos pieds.

Souvenez-vous de sa porte

Où brillait la botte d’or.

Aujourd'hui la botte dort;

On la dirait presque morte:

Aurait-elle, hélas! si tôt

Un pied dedans le tombeau?

Berthelon avait une âme,

Une âme d'artiste en fin

Et pour la chaussure enfin

Était bien aimé des dames,

Et même pour les semell(es)

Plus fort que feu Raphaël. 


\section{Auguste Berthelon: his Veritable Complaint}

DEATH TO POSTMODERN ART TO THE TUNE OF...

IN HIS SAN CREPINA VILLA (ROUTE DE PARIS)

Ah! Let's sing ourselves hoarse

With the last song of the shoe-

Maker snapping his awl in two!

At the top of our voices of course.

Then, with onions, let's weep on

For Mr Berthelon's Erewhon.

He goes down the quarry on foot

In any shoes he could wish

(Covered in glorious polish):

Sandal, mule or riding boot;

Being so active with skins

He's losing the time for lie-ins.

Aha! seeing that tears are seeping

From all the soft corns on earth:

He'll be getting his money's worth

To have real tears weeping

From our feet and collected as if in a stoup

By a gendarme's great big boot.

Remember how he would keep

A golden boot that shone hello?

These days the boot is asleep;

You'd think it was dying to go:

Could it have got, alas! so soon,

One foot in the grave by noon?

Now Berthelon had a soul

- The soul of an artist to boot -

And when it came to his shoes

The ladies were keen to extol

His uppers and fall for his soles

Even more than old Plimsoll's. 
Mais ce n'est pas de lierre

Qu'il faut lui ceindre le front:

La palme et le laurier sont

Des plantes trop éphémères;

Seule la plante des pieds

À son front serein sied.

Va verdir sur les pelouses

De Villa San Crepina!

Là peut-être te suivra

Quelque fin pied d'Andalouse,

Avec l'Andalouse au bout

Et... et le pied mène à tout.

Plus n'iront filles mutines

Au cour pur de Berthelon

Mesurer à l'étalon

Les talons de leurs bottines

Aux talons de Berthelon

Qui trouve son état long!

Ah, quand la barque horrifique

D'un dernier coup de tranchet

Tranchera son cordonnet,

Dieu donnera sa pratique

En disant dans sa tendress(e):

"Berthelon, vide pedes."

Que l'encens de nos chaussures

S'exhale avec Saint-Crépin

Emportant contre son sein

Cette âme à juste mesure

Qui n’aura jamais souillé, Jamais, lâme d'un soulier.

On salera dans une urne

Sa peau, le plus doux des cuirs.

Les grâces de l'avenir

S'en feront faire un cothurne

Pour aller danser au son

De l'hymne de Berthelon! 
But ivy isn't the plant you

Will want to circle his brow, And laurel and palm are now

Far too ephemeral too;

It's only by planting his feet

That things for him stay sweet.

Go and turn green on the lawns

Of Villa San Crepina!

There the delicate foot of Athena

Might be the end of one who fawns

On you when you're spinning a yarn.

But you may have her socks to darn.

Berthelon's pure heart is heartsick:

Rebellious girls just freeze,

Can't measure by the yardstick

The heels of their bootees

Against the heels of Berthelon

Inching away when they're so long!

Ah! when the horrid boat

Cuts off its mooring rope

With a final slicing move -

God will slide into the groove

Saying in his tenderness:

"Berthelon, vide pedes."

Let the incense from our shoes

Be exhaled when Saint Crispin

Bears off on his chest a wisp

Of esparto he isn't likely to lose;

And it will never have soiled

The soul of a shoe that's soled.

They'll salt his skin in an urn

- It's the softest of leathers.

The graces of future weathers

Will cause a buskin to turn

To go and dance to the sound

Of Berthelon's hymn-cum-round! 


\section{Ode aux Déperrier par M. de Malherbe}

\section{SUR LES ÉMANATIONS DE L'ÉCURIE DU REZ-DE-CHAUSSÉE} ET LES TUYAUX DU SECOND, MAISON CORBIËRE N ${ }^{\circ} 38$

Et le flot montait toujours.

Cette odeur, Déperrier, sera donc éternelle!

Le purin de nos cours

À côté du caca de tes commis ruisselle

Et ruisselle toujours!

Lordure du second, au premier descendue

Par le canal d'en bas

Et du rez-de-chaussée à létage rendue,

Ne sévapore pas.

La fiente a son odeur à nulle autre pareille:

Une odeur de fumier,

Si vous bouchez le nez, elle entre par l'oreille,

Ô messieurs du Premier!

Le pauvre en sa cabane où le chaume le couvre

La garde sous ses toits;

Et l'empereur se pince en ses closets du Louvre

Le nez avec ses doigts. 
Ode to the Déperriers

by Monsieur de Malherbe

ON THE EMANATIONS FROM THE STABLE ON THE

GROUND FLOOR AND THE PIPES ON THE SECOND

FLOOR OF THE CORBIĖRES' HOUSE N ${ }^{\mathrm{O}} 38$

And the waves kept rising.

So this stench, Déperrier, will last to eternity!

The manure that's gunning

Through our yards, will, with your stable-hands' shite, be

Eternally running!

The filth from the second floor, having burst

Down the fall-pipe at a rate

And shot back up from ground floor to first,

Does not evaporate.

Such crap has a pong like nothing else, I fear:

It's a dung-heap aroma -

If you hold your nose, it enters through the ear,

Putting first-floor folk in a coma!

The poor man's in his thatched-over doss: it

Harbours a niff that lingers

And the emperor in his Louvre water-closet

Pinches his nose with his fingers.

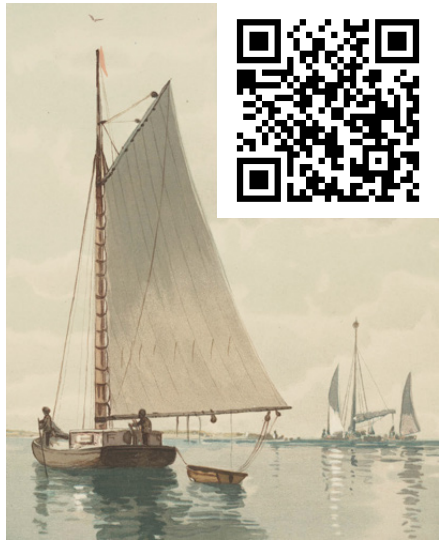

Video 8: Ode aux Déperrier par M. de Malherbe / Ode to the Déperriers by M. de Malherbe Watch a reading of this poem at https://doi.org/10.22599/Corbiere.8 or scan the QR code. 
100 Oysters, nightingales and cooking pots

Nous sommes en ce monde où porte chaque chose Lodeur de son destin.

Vous le sentez, messieurs, la rose sent la rose, Le purin, le purin! 
In this world, before everything decomposes,

Each thing has a stink to fit.

You sniff them, gentlemen: the rose smells like roses,

And the shit like shit! 


\section{À Madame Millet}

\section{(Air de Maître Corbeau.)}

Pour répondre, madame, à vos gracieux vers, Que ne me pousse-t-il des plumes de Guilmers! Dans mon estime encor si vous faites un bond, Ma foi, vous risquez bien de crever le plafond!

Comme on mène à la foire un vieux bouc embêté Je mène mon Panneau vers l'immortalité; Et quand des plats débris d'un jaunissant greffier Je fabrique une lyre, il doit être très fier!

Mais j'ai hurlé mes vers dans tous les caboulots À la lune, au soleil, aux ondes, aux échos. Huîtres et rossignols, marmites, violon Répètent à l’envi: "Voici le grefillon!"

Et que me font, morbleu, les cris et les cancans, Les Panneaux, les Baquet, leurs femmes, leurs enfants? Il me faut un greffier par jour à seriner: Ça m’est indispensable autant que mon dîner.

Je n'ai peur de rien, moi!... pas peur du choléra, Pas peur de la trichine, et même... et cætera! Qu'on déchaîne sur moi le greffe et le barreau, Je ne me cacherai derrière aucun Panneau!

Sachez que dans la peau d'un fils, quoique souffrant, Loge un gredin de cœur cloué solidement, Je n'ai pas peur de l'eau, je n'ai pas peur des cieux. ... Ah! si! pourtant: j'ai peur de deux grands coquins d'yeux!

De deux grands coquins d'yeux!... vous n'en saurez pas plus. Agréez, s'il vous plaît, mes très humbles saluts, Et quand voudra ma muse entonner sa chanson, Le Panneau vibrera!... C'est lui le diapason! 


\section{To Madame Millet}

(to the tune of Maître Corbeau)

To reply, Ma'm, to your gracious lines, which redound On me, I must say straight away and with feeling: If you go up in my esteem with another bound, Heavens, you'll very likely go through the ceiling!

Like they drag a cross old billy-goat to the fair, I hoick my Bill Board towards immortality where I fashion a guitar from his remains - he's cowed And flat, a yellowing clerk - He must be very proud!

But I have bellowed my verses in seedy bistros, Howled at the moon, at the sun, at waves, at echoes. Oysters and nightingales, cooking pots, a violin Vie in repeating "Hey here comes the scribbler-in!"

And how do they affect me, the shouts and ad-libs Of the Bill Boards, the Tub-thumpers, their wives, their kids? I need a Recorder by day to graft 'em on my ribs: They're as indispensable to me as dinner is.

I'm not afraid of anything, me!... not cholera, Not diddling or fiddling, and not ... et cetera! Let 'em unleash on me the Recorder recording, You won't find me hiding behind any Hoarding!

Know that in the skin of someone's son, though it aches, There lodges a knave of hearts who is firmly staked, I don't fear water, I'm not afraid of the skies.

— Ah! but I am afraid of two big cheeky eyes!

Two cheeky big eyes!... I won't mention them again.

Please accept my humblest greetings and then When my muse is wanting to break into song, Bill Board will vibrate!... He's the diapason! 
104 Oysters, nightingales and cooking pots

\title{
Sous une photographie
}

\author{
de Corbière
}

Aïe aïe aïe, aïe aïe aïe

Aïe aïe aïe qu'il est laid!

V'là c'que c'est

C'est bien fait

fallait pas qu'y aille (bis)

fair'son portrait 


\section{On a photo of Corbière}

Oh no no no, what a sight!

He's so ugly, such a fright!

It's a swiz

But there it is

Never should 've had it taken (repeat)

That phiz of his

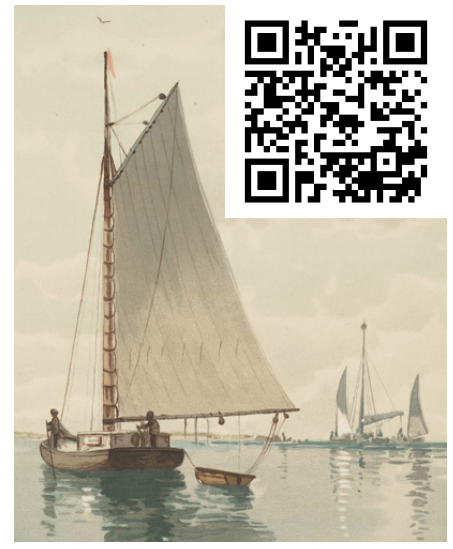

Video 9: Sous une photographie de Corbière / On a photo of Corbière Watch a reading of this poem at https://doi.org/10.22599/ Corbiere.9 or scan the QR code. 


\section{Légende Incomprise de l'Apothicaire Danet}

I

Maître Danet dans sa louche officine

Cherchait un soir,

Non pas non pas sa longue carabine,

Mais son Clysoir!...

Il s'agissait pour notre vieux nain-jaune

de dégraver

L'anus soufflé d'une pleine matrone

près de crever,

Oui, près de crever.

II

En la pointant droit au bas de l'échine

Danet crut voir

Un animal qui lui fesait la mine

Dans son trou noir!..

C'était un chat que la grosse cochonne

prise de faim

Avait lappé dans sa rage gloutonne,

Comme un lapin

Oui comme un lapin!

III

Jamais encor, se dit l'apothicaire

Courbant son front

non je n'ai bu dans ma vaste carrière

pareil affront!

J'ai bien tiré sur plus d'une gouttière

Des chats tout frais...

Mais un vieux chat au fond d'un vieux derrière

Jamais jamais

Non jamais jamais!

IV

Sur le devant de ma chère boutique

Dont jétais fou!

Qu'on place au lieu du serpent symbolique

ce vil matou!

Ah! dit l'artiste en dévorant ses larmes

J'ai trop vécu!

Je m’en punis et... je brise mes armes

sur ce vieux cu

Oui sur ce vieux cu! 


\section{Misunderstood legend of Danet the apothecary}

\section{I}

Maître Danet - in his dispensary at dusk - it

's a shady-looking dump -

Was searching high and low, no not for his musket,

But his Enema-pump!...

For what our sallow-faced old dwarf had to do first

Was unclag

The overfull anus, about to burst,

Of an overblown hag,

Yes, an overblown hag.

II

On aiming this pump below the base of her spine

Danet thought he saw

A dirty great beast giving him the evil eye

From inside her black maw!...

It was a cat that the enormous fat slut,

Racked by her habit

Of lapping things up, had lapped up, out to glut

Herself like a rabbit,

Yes like a rabbit!

III

Never before, swore the apothecary, with a hollow

Voice - he was bearing the brunt -

No never in my whole career have I had to swallow

Such an affront!

I've pulled cats out of gutters times out of mind,

Blind drunk? or run over?...

But one old moggy from the depths of an ancient behind,

Never never never

No not ever!

IV

As a sign for my shop whose praises I've sung

So often, and one that

Can replace the symbolic snake, let there be hung

This hideous tom-cat!

Ah! said the artist, as he choked back his tears,

I just can't cope - it's a farce!

I've lived too long to see you tug it by its ears

From this old arse,

Yes this old arse! 


\section{La Complaincte Morlaisienne}

Ousque sont habillés [sic] en grande tenue les édilités et autres et mis sur l'air de Fualdès par le sieur Corbière Édouard et ousque sont apostillées et sublignées les plus espirituelles choses pour le plus grand esbastement des obstus d'esprit -

Ciel quel est ce commissaire Qu'on voit surgir sur nos bords, Parmi sétrons et rats morts, Du sein doux de notre maire?! Pour ce qui est des pieds des mains, Il a la forme d'un humain.

II

Mais son cœur est anathème!! ... Pour tous ses administrés Il fait vœu de chasteté sortant du quarant'huitième, Et sans pitié il défend Aux femmes de fair' des enfants.

III

Ce bipède vraiment inique, (Qui n'a pas d'larmes dans les yeux?) Envoie à des hommes vertueux des brevets de filles publiques! Ce qui est très inouï Oh oui, pour très inouii, oui!

IV

Pour comble de désespérance savez-vous ce qu'il advint? Un' déconfitur' d'adjoints! Pauvre, pauvre, pauvre France! ... Et pourtant le soleil parcourait le ciel sur son char. 


\section{The Morlaisian Lament}

In which are dressed in fine array the aediles and their ilk and set to the tune of Fualdès by sire Corbière Édouard and in which are added apostillations and addendata, the most witty matters for the greatest diversion of the obtuse in spirit -

I

Heavens who's this prefect Of police just emerging from our river Among dead rats and slivers Of the soft soap of our mayor-elect?! It looks from his feet and hands That he's human, and like a human stands.

II

But his heart is anathema!! ... For the sake of the community He takes a vow of chastity On reaching his $49^{\text {th }}$ summer, And showing no pity, he forbids All women to have kids.

III

This diabolical biped (With never a tear in his eyes?) Sends to men of virtue prize Certificates for whoring in bed! That's unheard-of, a cock-up, A right mock of living it up!

IV

To add to the depths of despair D' you know what came about? A bunch of deputy mayors in rout! That's poor, poor France down there! ... And yet his Lord the Sun scuttled through the sky in his chariot. 
Pharaon ce commissaire de police des hébreux Les fricassait comm' des œufs ce qui était un'grande misère Mais près d'çui çi Pharaon nétait qu'un petit polisson.

$\mathrm{Vl}$

Hélas il avait prestance D'un Thug ou même de deux, Ce qui partout faisait que il portait l'horrifiscence, tel que l'vieillard le plus vieil ne vit rien jamais d'pareil.

\section{VII}

Il était très délétère, Mais Dieu qu'est fort comme il faut voulut mettre fin à nos maux sans mettre fin au commissaire; Enfant j'vas vous dire c'qu'il fit dedans le couplet qui suit -

\section{VIII}

Vite il expectore un ange sous l'espèce d'un sous-préfet Pour redresser tant d'forfaits, avec des galons aux manches Et même je crois qu'il en avait sur l'tempérament

\section{IX}

très pareil aux alouettes qu'on attire par le miroir Le peuple est sorti pour voir Le sous-préfet en lunettes. C'qui fait qu'on pleurra (sic) longtemps dans tout l'arrondissement. 
This Pharaoh boss-at-any-price, Chief Chef of the Hebrews, Fricasséed them like egg stews

- Which wasn't very nice...

Beside him the real Pharaoh bod

Was nothing more than little sod.

VI

Alas he had th' imposing presence

Of a Thug or even a couple

Which means that he caused trouble

Everywhere, and horrifiscence,

So much so that the oldest old tyke

Had never seen anything like.

\section{VII}

With him perniciousness was rife But God who's strong as everyone knows

Wanted to put an end to our woes

Without ending the prefect's life;

Child I'll tell what he went on to do

In the ensuing verse or two -

VIII

Quickly he spits out an angel

Dressed as a sub-prefect who might

Put so many ills to rights,

He'd braid on his sleeves as well;

Even had braid I believe

On his moods as well as his sleeve,

IX

Very like skylarks, masses

Of which can be mirror-attracted.

Locals came out to see how he acted

When he (sub-prefect) put on his glasses.

Which is why they wept for ages

In all local parochial places. 


\section{X}

Mais voilà ce peuple impie Qui, ne le comprenant pas, le prend, oui le prend hélas Pour l'caissier d' la gendarmerie, N'avait-il donc pas au front une auréole oui-t-ou non

\section{XI}

La canaill' piaille et criaille

En braillant des braillements.

Par derrière et par devant, on dirait que le cri aille en tel rut que sire écho En prit mal dans les boyaux:

\section{XII}

"Accourez à ma revanche "avec vos bottes et vos pieds "vous portant jaunes baudriers "vous portant sardines blanches "Et coupez-leur le sifflet "avec votre grand sabre et $-\ldots$

\section{XIII}

... cætera!" v'là l' sang qui coulera tout à l'heur' dans l' bassin car l'on va mettre bas cinq des têtes de cette foule! les ventres vont être décousis avec tout ce qui s'en suit.

\section{XIV}

Le commissaire, fils de chienne Et crocodile ennuyeux comme feu Néron mit le feu à un' lanterne vénitienne qu'il avait, de par ma foy, prise à crédit chez Leroy. 


$$
\mathrm{X}
$$

But these impious people, see, Not grasping what he's about, Take him, yes they make him out To be cashier of the gendarmerie, Hadn't he over his head a halo, Well, hadn't he, yes or no?

\section{XI}

The squawking and bawling rabble Do nothing but squeal and screech From every quarter and each to each So loud that their hyper-babble Is on heat and Sir Echo's guts Feel churned up so much that it hurts:

\section{XII}

"Take a run at all these types

To avenge me with boots and kicks, Wearing your yellow baldrick, Wearing your sergeant's stripes And cut them off mid-word With your super whopping sword...

\section{XIII}

Etcetera!" And blood in due Time will flow into the wet-dock For five of them will be hacked off Five of the heads of this crew! Their bellies will then be slit And whatever follows from it.

\section{XIV}

Our detective, son of a bitch And his boring old crocodile sire, Like once fiery Nero, set fire To a Venetian lantern which He had bought, well, no, I swear... He got it on tick at Leclerc. 


\section{XV}

Mais v'là Leroy qu'est un ange

(g'na des anges qui sont pompiers)

d'un nez fort embrasse les pieds

des gens d'armes en phalanges

On ne dégainera jamais

Devant l'peuple de Morlaix!!

XVI

Cela est si mirifique

Pour les générations

Futures, qu'il est question

de mettre Leroy en musique;

musique de violon...

gens subtils me comprendront.

\section{XVII}

V'là l'tribunal dans la salle, Un président d'enfer naît mais pour ce qui est du nez vraiment Collinet l'a sâle [sic] l'yant fourré trop avant Dans le cas des délinquants! -

\section{XVIII}

Bien vite instruisent l'affaire Collinet et D’amphernet Car ils avaient tous des nez pour espionner nos derrières et des nez qu'ils déguénaient [sic] contre le peuple de Morlaix.

\section{XIX}

L'procureur lève sur la troupe Une noble tête à cheveux blancs que les coupables doivent souvent voir se dresser dans leur soupe...! Un' belle tête de vieillard qu'est très éloquente, car... 
XV

But Leclerc who's really angelic

(Some angels extinguish fires, some eat)

With an effort kisses the feet

Of phalanxes of military dicks.

Unsheathing would be a joke

When faced with Morlaix folk!!

It's absolutely terrific

For future generations

That there are deliberations

On setting Leclerc to music;

Sing Sing for violin, with a twist...

Subtle folk will get my gist.

\section{XVII}

When the case comes up in court

A presiding president is born

But when it comes to being sworn,

Peabody who's the swearing sort

Has stuck his nose up to his chin

In the delinquents' swearing-in! -

\section{XVIII}

Peabody and de Netherparts,

Quick at adopting poses,

Have such practised noses

For sniffing out old farts

And noses that they've thumbed to say

Nuts to the folk of old Morlaix.

\section{XIX}

The prosecutor raises his pate

Above the culprits there in a troupe

- A white-haired head they must hate

To see now that they're in the soup...!

A handsome old man then

Who's eloquence itself, when... 
II6 Oysters, nightingales and cooking pots

\section{XX}

Il les condamne à la peine

Pour cause de châtiment

et sans plus de sacrement

En prison on les rengaine!

On ne dégainera jamais

Contre le peuple de Morlaix. 
$\mathrm{XX}$

He sentences them - fate sealed,

Punishment assigned and

Last rites being out of hand

'Tis to prison they are wheeled!

No one must ever put a spoke

In the wheels of good Morlaix folk. 


\section{L'hymne nuptial}

(Air: Partant pour la Syrie.)

Fixée en Algérie

La smala des Guéguen

Pensait coucher Marie

En mâle marocain.

Tous étaient dans l'attente

D'un turco vert-de-gris.

La voici sous la tente

D’un blanc... le blanc Legris.

Il faut un dromadaire

Dans ce désert du cœur

Et ce tendre homme adhère

Ce jour à ce bonheur.

Il vit les sauterelles

Dans son lit sans effroi

Et cependant près d'elle

I1 se sent plein d'émoi.

Il lui dit: "De mon âme

Vous êtes l'oasis,

À vos genoux, ma flamme..."

— "Oh! monsieur, oh! assis."

Assis, il dit: "Gazelle,

Je demande ta main!"

Soupirant au gaz elle

Lui répond: "Oh! demain!"

— "J’habite l'Algérie

Et c'est Oran où tend

Ici, dans ma partie

Lespoir d'avancement."

À ces mots chacun pousse

Au sein du Sirocco

Une larme si douce

Que c'est plus sirop qu'eau. 


\section{Nuptial hymn}

(to the tune of Off to Syria by sea)

In an Algerian marquee

The tribe known as Guéguen

Thought they'd bed Marie

As a Moroccan Jaeger.

All, on tenterhooks, went

The turco verdigris way

But she slipped into the tent

Of a white... no, a livid grey.

A dromedary, being called for

In this desert of the heart,

A soft-hearted hump-back's all for

Taking the amorous part.

He spots bed-bugs and cicadas

But they do not irk him;

Not one to cause her ardours,

He fears that she might shirk him.

He said to her: "I adore you,

You're the oasis of my soul.

On my knees I implore you,

Sweetheart..." "Oh! you are too bold,

Sir! please sit." He sat. Then said:

"If you wed anyone, my baby

Belling, my gazelle, if you wed,

Let it be me..." "Tomorrow, maybe."

"As I am from Algeria,

Oran is where I'll look

For advancement, my ulterior

Aim is... to suit my book."

At which words the seers

Are swimming like a guppy

In a gentle flood of tears

With salt water in but syrupy. 

Alternative version of Nuptial hymn

(to the tune of Off to Syria by sea)

In an Algerian marquee

A tribe known as Guéguen

Thought they'd bed Marie

As a Moroccan pagan.

Everyone on tenterhooks,

With a no-one's-to-blame air,

Awaited khaki pasty cooks

And the livid grey mayor.

A dromedary being needed

In this desert of the heart,

One hump-back man is weeded

Out for the amorous part.

He spotted bed-bugs and hoppers

But they didn't irk him;

Not one of your heart-stoppers

- Yet she didn't shirk him.

He says to her: "I’ve come to claim

The oasis of my soul."

"You'd whore us!" "My blue flame,

O Isis!" "O mice hole

- From which you'd gnaw the veil!"

He blows a kiss: "My baby

Belling, my gazelle, if you fail

To marry me..." “Tomorrow, maybe."

"As I am from Algeria,

Oran is where I'll look

For a career that is cheerier

Than the ones I forsook."

"Who's crying now? Have no fears!

You're swimming like a guppy

In a gentle flood of tears

Less watery than syrupy." 


\section{Les Pannoïdes}

OU LES TROIS MYSTÈRES

DU GREFFIER PANNEAU

SAVOIR: $1^{\circ}$ LES FIANÇAILLES

$2^{\circ}$ LA CONCEPTION $-3^{\circ}$ L ENFANTEMENT

ler MYSTÈRE $^{\text {er }}$

Arrivée à Chateau-Gonthier [sic]

chez le mélophage et beau-père Parisot

Un beau jour sur Chateau-Gonthier [sic]

Se posait un jeune greffier.

Il était frais, svelte et volage

Comme l'est un greffier à lâge

De vingt à cinquante-cinq ans,

Et par un matin de printemps.

Bien longtems [sic] des maux d'estomac

Le berçaient dans le célibat.

Aujourd'hui qu'il a le corps libre,

Lamour a fait vibrer sa fibre

dans l'appareil de digestion...

Enfin c'est un vrai papillon.

Que peut faire à Chateau-Gonthier [sic]

ce pa pa papillon-greffier?

Parbleu! s'annexer Adrienne,

(Grand bien lui advienne)

Sous la baguette de l'amour

Son cœur bat comme un doux tambour.

Il sonne, il entre... il est entré!

En plein dans l'asile adoré...

Il voit son amante accroupie

virant l'orgue de Barbarie

Et le vieux papa Parisot

Clapottant [sic] sur son bon piano. 


\section{Pannic Days}

OR THE THREE MYSTERIES OF

THE CLERK OF COURT NAMED PANNEAU

THAT IS $1^{\circ}$ THE ENGAGEMENT

$2^{\circ}$ THE CONCEPTION $3^{\circ}$ THE CHILDBIRTH

$1^{\text {st }}$ MYSTERY
THE ENGAGEMENT
Arrival at Chateau-Gonthier
residence of the melophile melomaniac
and father-in-law Parisot alias Parisilly.

One fine day a young clerk of court Landed at Chateau-Gonthier. By report Fresh-faced, fickle and svelt As court clerks are - they're dealt Such traits aged twenty to fifty-five In Spring when it's good to be alive.

For a very long time his stomach aches Kept him out of the marital stakes.

Now that his body can ignore his liver Love has made his very fibre quiver Down his digestive apparatus...

Granting it special butterfly status.

What can this bub-bub-butterfly clerk Do in Chateau-Gonthier's park?

Dammit! annex Adrienne to himself, (May such an act bring him great wealth) Conducted by love's baton tum tum His heart beats like a muffled drum.

He rings, he enters... now he's inside! Fully ensconced where he loves to hide... He sees his sweetheart crouching, sturdy At winding up the hurdy gurdy And dear old daddy Parisot Tinkling away on his pi-an-o. 
Les voilà tous trois dans les bras

De l'un de l'autre... Et cætera...

"Panneau, qu'une union si chère

“Te rende un jour Père,

"Adrienne mère,

"Parisot grand-père,

"Dessur la tête d'un enfant

"Paraphé bien légalement."

\section{$2^{\mathrm{e}}$ MYSTÈRE}

\section{LA CONCEPTION}

AY PANNEAU

imitado de l'Español Ay Chiquità

Lon dit, Panneau, que ta femme

(Ici, bien mon compliment)

Va bientôt greffer ta flamme

Sur la tête d'un enfant!...

En passant devant ta porte,

Me promenant à l'œil nu,

J'ai vu (le Diable m'emporte!)

Quelque chose de... cornu!

Mais qui voudrait, si l'infidèle

Voulait te percher le front,

Collaborer avec elle,

Avec elle! ah quelle [sic] affront!

Qui pourrait avec la rebelle

Ay Panneau ô ô ô ô ô

Qui voudrait?... Ah, greffier modèle

$\mathrm{Tu}$ peux porter le front haut.

Ces cornes c'est une biche

Qui pour la maternité

A partagé... mais je m’en fiche.

Quant à la paternité,

Lorsque l'épouse est volage,

Il faut avoir sous la main, pour les cornes du ménage,

une chèvre, c'est tres sain. 
There all the three of them are

In each other's arms... Et cæera...

"Panneau, from such a union may

You become a father one day,

Adrienne a mother-to-be,

And Parisot a granddad and see

Everything sworn on the head of a child,

Everything legally signed and filed."

$2^{\text {nd }}$ mystery

THE CONCEPTION

Ay Panneau

imitado de l'Español Ay Chiquitâ

They say, Panneau, that your wife

(Here I'm being complimentary)

Will shortly be grafting your love-life

Onto the head of a baby!...

As I was passing your entry

And keeping my eyes skinned

I happened to sniff (the Devil take me)

Something... horny in the wind!

But whod like it if the deceiver

Wanted you to try out a stunt,

That is: collaborate with her,

With her! ah what an affront!

Who could with such a spark

Aye Panneau oh with an oh to spare

Who'd want it?... Ah, model clerk,

You can carry your head in the air.

These horns belong to a hind

Who for maternity to occur

Shared her with ... Well never mind.

As for paternity (from păter)

When the spouse is flighty and supple

It's best to have, so there's no fuss,

As the horns for such a couple

A goat's, 'tis healthier thus. 
Mais, bon-Jésus! si l'infidèle

Rêvait d'ombrager ton front

Qui voudrait rêver avec Elle?

Pas moi! non non quel affront!

Qui voudrait hélas avec celle

Ay Panneau ô ô ô ô ô.

Tu n'as pas besoin d'ombrelle

$\mathrm{Tu}$ peux tenir ton chapeau.

Mais, prends garde dans l'église

En portant le nourrisson

De l'appeler Artémise

(Surtout si c'est un garçon)

Pour le sexe des familles

Il faut voir les médecins

Sans quoi l'on verrait des filles

gendarmes et capucins!

Quand jai fait cette complainte

Ma Muse avait mal aux reins.

Elle aussi se trouvait enceinte

il me fallut un parrain.

Et c'est toi, greffier lyrique,

Ay Panneau ô ô ô ô ô

Toi que j’ai mis en musique

Pour violon et Pariseau!

$3^{\text {e }}$ ET DERNIER MYSTÈRE

L'ENFANTEMENT DU GREFFIER

(pot-pourri)

$1^{\circ}$ Air du Noël d'Adam

Minuit! greffier, c'est l'heure solennelle, Ouvrez-moi l'œil, ô Muses d'alentour! Panneau, debout! allume la chandelle, À ton enfant il faut donner le jour. Vois Adrienne en travail, en souffrance. Je crois qu'il faut lui chauffer un bouillon - Pointu! Voici l'heure de délivrance!

Noël, Noël, voici le greffillon!

Noël, voici le greffillon! 
But, Jesus! if the deceiver

Dreamt that you should bear the brunt, Who'd want to dream with Her?

Not me! no no, what an affront!

Who'd want alas to come to her aid Aye Panneau oh but what's it matter? You won't be needing a sunshade You can rely on the hatter.

Do make sure, please oh please, When you bring your pride and joy To church to call it Artemise (Especially if it's a boy).

Regarding sex in family trees

You'll need to see the doctors Or you might get women priests Or gendarmes and holy proctors!

When I'd written this complaint My Muse had aches in her back. She found she too was pregnant A godfather was what I lacked. And it's you, clerk, as you're lyrical, Aye Panneau oh I'll be pally! I've written you in a musical For violin and Tin Pan Alley!

$3^{\text {rd }}$ and last mystery THE CLERK OF COURT'S BIRTH (medley)

$1^{\circ}$ to the tune of Adam's Carol

Midnight! clerk, it's the solemn hour, Open your eyes, O Muses of hereabout! Get up, Panneau, light the candle now, It's time to give birth, to let your baby out. See Adrienne in travail, she's started to suffer, I think we should warm up some broth for her - It's time for deliverance from the dark! Noël, Noël, here comes the baby clerk! Noël, here comes the baby clerk! 
$2^{\circ}$ Air sérénade de Gounod

Parisot calme et pure

Ronflant, rêvant basson...

Il entend un murmure

Et passe un caleçon,

Son contour se révèle

Sans apprêt, sans atour.

Portez de la flanelle (bis

La nuit comme le jour )

$3^{\circ}$ Air de Gastibelza

Panneau lui dit en degaînant [sic] sa bourse D'un de ses flancs:

"Va me louer une bonne à la course, "Voici deux francs!

"Chez le docteur pousse-la ventre à terre,

"Docteur Bozec

"Et lui, qu'il vogue en chemise légère:

"Le baromètre est à Beau-sec!

"Oui, à Beau-sec!"

$4^{\circ}$ Air de la Retraite

Bozec se lève, il vole, mais sans aile,

Sous son aisselle,

Oui, mais il prend

Sous l' bras un instrument,

Un instrument,

Oh mais un instrument

Beaucoup plus grand

q'pour extirper un'dent.

$5^{\circ}$ Air de St Roch

Il vole donc, pas au vol, mais en nage

Et, sur le sein des Panneaux aux abois...

... (ma Muse ici s'est voilé le visage,

De ses deux mains,... pour voir entre ses doigts)

"Voyons, cocotte,

“Qu'est-c'qu'on tripotte [sic]

"Mais un Panneau

"Nous bouche le tableau." 
$2^{\circ}$ to the tune of Gounod's Serenade

Parisot, not in a jumble, Snoring, dreams bassoon... Hears his tummy rumble

Slips on his pantaloon!

His outline is plain to see -

No finery, no fine array.

Wear your flannel nightie (repeat

Both night and day! )

$3^{\circ}$ to the tune of Gastibelza

Panneau said to him on unsheathing his purse

From one of his shanks:

"Go and hire me a maid at the shops and disburse

These two new francs!

Push her then to the doctor's, belly to the ground...

As for Doctor Bozec,

Let him sail off in the light shirt he's found:

The barometer reads Fine and dry!

Which, in French, is Beau-sec!"

$4^{\circ}$ to the tune of The Retreat

Bozec stands, flies, without any wings

In his armpits,

Yes, but he fits

Under his arm an instrument,

An instrument,

Oh it's some instrument,

A much bigger factor

Than a tooth-root extractor.

$5^{\circ}$ to the tune of St Roch

He's running, in a sweat, not the tide race

And, on the Panneaux' bosom lingers...

... (here my Muse has veiled her face

With both hands,... to peep between her fingers)

"Now then, cottonsocks,

What are they pawing,

But a Panneau

Has blocked out the drawing." 
$6^{\circ}$ Air du jeune greffier

Crac le v'là! qui? parbleu, l’enfant!

Tout au bout du grand instrument

Grand Dieu, si c'est là ton image

T'as un' drôl' de ball' pour ton âge,

Pardonne aux Panneau cet affront,

Ils ne savent plus ce qu'ils font!

$7^{\circ}$ et dernier

Air des Montagnes dans la Dame blanche

Sonnez, sonnez, sonnez, forceps et serinette!

Tous les Panneau et Pariseau sont réunis

Un gréfillon c'est une fête

Pour le greffier qui l'a commis!

Sonnez, sonnez, cordons de sonnette

Tout ahuri, Bozec s'enfuit,

Un gréfillon ce n'est pas fête

Pour un docteur surtout la nuit.

Sonnez $[\ldots]$ Etc. 
$6^{\circ}$ to The young clerk of court's tune

Hell! there he is! who? the nipper!

Right on the big instrument's tip.

Cripes, if that's meant to be you he's skewing it, Giving you that funny old face as a stunt.

Forgive the Panneaux kids this affront, They're not aware that they're doing it!

$7^{\circ}$ and last

Mountain tune from The White Lady

Ring, ring, ring, forceps and canary voice!

All Panneaux and Parisots have convened.

A baby clerk's a call to rejoice

For the clerk who did the deed, the fiend!

Ring, ring, with strings of the bell-pull - quite

Flabbergasted, Bozec takes flight,

A baby clerk is not a delight

For a doctor especially at night.

Ring [...] Etc. 